\title{
Race Characterization of Puccinia striiformis f. sp. tritici, the Cause of Wheat Stripe Rust, in Saskatchewan and Southern Alberta, Canada and Virulence Comparison with Races from the United States
}

\author{
G. S. Brar and H. R. Kutcher, Crop Development Centre, Department of Plant Sciences, University of Saskatchewan, Saskatoon, SK S7N
} 5A8, Canada

\begin{abstract}
Brar, G. S., and Kutcher, H. R. 2016. Race characterization of Puccinia striiformis f. sp. tritici, the cause of wheat stripe rust, in Saskatchewan and southern Alberta, Canada and virulence comparison with races from the United States. Plant Dis. 100:1744-1753.

Wheat stripe rust, caused by Puccinia striiformis f. sp. tritici, has been common across Saskatchewan, Canada since 2000. Fifty-nine isolates of $P$. striiformis f. sp. tritici, the majority of which were collected between 2011 and 2013 from Saskatchewan and southern Alberta, were analyzed for virulence frequency and diversity and compared with isolates characterized in the Pacific Northwest and Great Plains regions of the United States. In all, 31 wheat differentials, including 20 near-isogenic lines and 1 triticale variety, differentiated 59 P. striiformis f. sp. tritici isolates into 33 races, of which one race, C-PST-1, represented $31 \%$ of the isolates. None of the races were virulent on $Y r 5, \operatorname{Yr} 15$, or $\operatorname{YrSP}$. Virulence frequency ranged from 65 to $98 \%$ on $Y r A, Y r 2, Y r 8, Y r 9, Y r 27, Y r 29$, $\mathrm{Yr} 32, \mathrm{YrSu}$, 'Heines VII', and 'Nord Deprez'. Race C-PST-6 was virulent on the greatest number of the differentials $(n=25)$ and C-PST-18 on the fewest $(n=14)$. Discriminant analysis of principal components and

multivariate cluster analyses detected three and four major groups, respectively, which differed from each other in terms of virulence spectrum and year of collection. The diversity of the P. striiformis f. sp. tritici population in southern Alberta was greater than in Saskatchewan, which indicated that, although $P$. striiformis f. sp. tritici is primarily windborne over great distances and does not usually overwinter, there are detectable differences in virulence between these regions of western Canada. Comparative analyses of virulence frequency of Saskatchewan or southern Alberta isolates with isolates representing races from the Great Plains and the Pacific Northwest of the United States indicated greater similarity of Saskatchewan races to the Great Plains despite strong correlations with both parts of the United States. This suggests that the P. striiformis f. sp. tritici population in Saskatchewan is a mixture of inoculum from both parts of the United States.
\end{abstract}

The prairie provinces of western Canada (Alberta, Saskatchewan, and Manitoba) produce more than $85 \%$ of the wheat grown in Canada (Anonymous 2010), and it is Saskatchewan that is known as the "bread basket" and the "wheat province" of Canada (Marchildon 2009). In 2014, the crop was grown on over 13 million ha in Canada (http://statcan.gc.ca/), with production of 29 million t (Statistics Canada 2015). In the past 15 years, stripe rust of wheat, caused by Puccinia striiformis f. sp. tritici Erikss., was observed frequently in Saskatchewan, and a severe epidemic occurred in 2011 (Brar 2015; Brar et al. 2014, 2016), when yield losses were estimated to be as much as $35 \%$ (Kutcher et al. 2012). Stripe rust was first reported from Saskatchewan in 1928 but was not considered economically important (Line 2002), even though it was common on native grass species (Stubbs 1985). The greatest area of concern was southern Alberta, where stripe rust was presumed to overwinter and was a major production problem, particularly for farmers growing soft white wheat under irrigation (Conner et al. 1988; Sanford and Broadfoot 1932). Epidemics of wheat stripe rust were reported in Alberta in the 1990s (Kumar et al. 2012) and an epidemic was reported in central Saskatchewan in 2006 (McCallum et al. 2007). An epidemic in 2005 in western Canada was partially the result of a severe stripe rust epidemic in the Pacific Northwest (PNW) of the United States, from which inoculum traveled by wind to southern Alberta and Saskatchewan (Turkington et al. 2009). This

Corresponding author: H. R. Kutcher; E-mail: randy.kutcher@usask.ca

*The $\boldsymbol{e}$-Xtra logo stands for "electronic extra" and indicates that three supplementary figures and two supplementary tables are published online.

Accepted for publication 1 April 2016.

http://dx.doi.org/10.1094/PDIS-12-15-1410-RE

(C) 2016 The American Phytopathological Society epidemic was further facilitated by cultivation of susceptible varieties, the possible overwintering of the pathogen (Xi et al. 2015), and changes in the pathogen virulence spectrum (Puchalski et al. 2013).

Isolates of $P$. striiformis $\mathrm{f}$. sp. tritici are separated into races based on their reaction on different wheat genotypes, referred to as differential wheat lines (Line 2002). Varieties with known resistance genes have been used extensively in North America to differentiate races (Su et al. 2003; Wan and Chen 2014). Near-isogenic wheat lines in 'Avocet' background were developed that are used by many researchers to differentiate races of the pathogen (Wellings et al. 2004). Races of $P$. striiformis f. sp. tritici were studied in central Alberta recently, revealing that the race structure is similar to that documented from the PNW of the United States (Holtz et al. 2013; Kumar et al. 2012).

Stripe rust has been a major problem in the PNW of the United States for many decades and the amount and virulence of stripe rust inoculum in Canada depends on the characteristics of the pathogen in the United States (Su et al. 2003; Xi et al. 2015). The western Canadian provinces of British Columbia, Alberta, Saskatchewan, and Manitoba are close to the stripe rust epidemiological regions R1, R2, R5, and R9 of the United States (Wan and Chen 2014). British Columbia is close to regions R1 and R5, Alberta to R2, and Saskatchewan and Manitoba to R9. The races common in these regions may be closely related to the races prevalent in western Canada because the inoculum is airborne. Currently, virulence characterization of $P$. striiformis $\mathrm{f}$. sp. tritici in western Canada, and Saskatchewan in particular, has not been compared with that in the United States.

Cultivation of varieties resistant to stripe rust is one of the most efficient methods of disease management and an environmentally friendly approach (Kumar et al. 2012; Wan and Chen, 2014; Xi et al. 2015). However, forces such as mutation and somatic hybridization can cause virulence changes within the pathogen population (Chen 2005) and selection pressure can favor such mutants or variants, resulting in dramatic changes in the race structure of a population. 
New races of this pathogen can rapidly increase in frequency and, as a result, resistant varieties often become susceptible after a few years. In 2000 , new, highly aggressive races with additional virulence were observed in the United States that caused disease symptoms on wheat cultivars carrying the $\operatorname{Yr} 8$ and $\operatorname{Yr} 9$ resistance $(R)$ genes (Chen 2005; Milus et al. 2006, 2009; Wan and Chen 2014). This was due to the introduction of a new $P$. striiformis $\mathrm{f}$. sp. tritici population that arose in Mexico, then spread north into the Great Plains (GP) region (Chen 2005). Effective mitigation of stripe rust through cultivar resistance and preemptive fungicide application depends on prior knowledge of pathogen virulence, which is gained by monitoring the pathogen populations on a regular basis (Su et al. 2003; Wan and Chen 2014).

Although the race characterization of $P$. striiformis f. sp. tritici was first conducted by Sanford and Broadfoot (1932) in western Canada, then by Su et al. (2003) and, more recently, by Kumar et al. (2012), and Holtz et al. (2013) in central Alberta, detailed knowledge of $P$. striiformis f. sp. tritici virulence in Saskatchewan and southern Alberta is lacking. Moreover, epidemics of stripe rust in 2005, 2006, and 2011 in western Canada make it imperative that we understand the virulence patterns of $P$. striiformis $\mathrm{f}$. sp. tritici. The present study was designed to study the virulence phenotypes of the population of $P$. striiformis f. sp. tritici in Saskatchewan and southern Alberta, plus six isolates from the provinces of Manitoba and British Columbia. The objectives were to (i) assess the race structure of $P$. striiformis $\mathrm{f}$. sp. tritici in Saskatchewan and southern Alberta in terms of virulence diversity and (ii) compare $P$. striiformis $\mathrm{f}$. sp. tritici virulence frequency on $\mathrm{Yr}$ genes (host resistance genes) from Saskatchewan with Alberta and with stripe rust epidemiological regions R1, R2, R4, R5, R8, and R9 of the United States, where stripe rust has been a problem for many years. Regions R1, R2, R4, and R5 (located in the PNW) are close to Alberta and stripe rust races in these regions are different from other regions, whereas R8 and R9 (located in much of the GP of the United States, and part of the Puccinia pathway) are close to Saskatchewan and stripe rust in these regions is generally not as severe as in the PNW. Throughout this article, regions R1, R2, R4, and R5 will be referred to as the PNW and R8 and R9 as the GP.

\section{Materials and Methods}

Sample collection and isolation of $P$. striiformis f. sp. tritici. In total, 59 isolates were obtained from infected wheat leaves collected from diseased wheat plants obtained from commercial wheat fields or breeding nurseries, with one additional isolate collected from foxtail barley (Hordeum jubatum). Most of the isolates originated from southern Alberta $(n=21)$ and from Saskatchewan $(n=32)$, and were supplemented with 5 from Manitoba and 1 from British Columbia. The majority of these 59 isolates were recovered from wheat leaves collected in 2011 and 2013 but isolates from $2005(n=4), 2007(n=$ 1), $2009(n=1), 2010(n=3)$, and $2012(n=2)$ were also included. Information on geographical location, host, and year of collection is provided in Supplementary Table S1. Diseased leaf samples were collected, dried in paper envelopes, and stored at $4{ }^{\circ} \mathrm{C}$ until processed. Colleagues from Alberta and Manitoba stored the isolates in a similar fashion after collection.

Genetically uniform isolates were obtained by transferring urediniospores from a single pustule or uredia on the leaf material collected onto one seedling of wheat line 'Avocet S' at the two-leaf stage using a very fine needle. This wheat genotype is susceptible to all known races of $P$. striiformis $\mathrm{f}$. sp. tritici in North America at the seedling stage (Wan and Chen 2014). Plants inoculated with different isolates were separated after inoculation by placing them in mini-chambers (rectangular cages covered with a plastic sheet) to prevent cross-contamination and kept in a dew chamber at $10^{\circ} \mathrm{C}$ for $48 \mathrm{~h}$ in the dark. The plants were then transferred to a growth chamber with a diurnal temperature cycle that gradually changed from 12 to $17^{\circ} \mathrm{C}$, with a 16 -h photoperiod and 60 to $80 \%$ relative humidity. Uredinia usually appeared on leaves 14 days postinoculation (dpi). Urediniospores were collected by tapping infected leaves over aluminum foil, and were cleaned to remove dust particles or plant tissue. Clean spores were placed into Eppendorf tubes and desiccated using silica at $4^{\circ} \mathrm{C}$ for at least 3 days before storage at $-80^{\circ} \mathrm{C}$.
Isolate characterization. Isolates of $P$. striiformis $\mathrm{f}$. sp. tritici were characterized on a differential set of 20 wheat lines in the Avocet spring wheat background and on 10 supplemental wheat lines, including some Canadian wheat varieties and the triticale 'Brevis' (Table 1). The commercial wheat varieties were added without any prior knowledge of resistance but were included because they were most widely cultivated in 2005 to 2013 (Anonymous 2010; Brar et al. 2016). Brevis triticale was included because it showed a very high level of resistance at the adult-plant stage in a study by Randhawa et al. (2012). Urediniospores (10 mg) of each isolate were added to $950 \mu \mathrm{l}$ of Bayol 35 (mineral oil) to inoculate eight seedlings at the two-leaf stage (when the second leaf was nearly fully expanded). Four seedlings, each in a single pot, constituted one replication in the experiment. The entire experiment was conducted twice. After inoculation, plants were maintained following the protocol above and infection types (IT) were assessed 14 dpi using a 0-to-9 scale modified from that of Line and Qayoum (1991) and McNeal et al. (1971), in that the leaf area covered with uredinia was rated by gathering information from both scales (Supplementary Table S2; Supplementary Fig. S1). The modified scale is based on the percentage of leaf surface area covered with uredinia or necrotic flecks and was better than either scale alone at distinguishing between IT 4 and 5, which were the critical scores separating avirulent from virulent isolates. While recording IT, both first and second leaves

Table 1. Wheat and triticale differential genotypes used to characterize races of Puccinia striiformis f. sp. tritici classified into groups based on diversity analyses by virulence frequency on each $\mathrm{Yr}$ gene

\begin{tabular}{|c|c|c|c|c|c|c|}
\hline \multirow[b]{2}{*}{ Diff $^{\mathbf{a}}$} & \multirow[b]{2}{*}{ Line with $Y r$ gene $^{b}$} & \multicolumn{5}{|c|}{$\begin{array}{l}P \text {. striiformis f. sp. tritici virulence } \\
\text { frequency }(\%)\end{array}$} \\
\hline & & All isolates & G1 & G2 & G3 & G4 \\
\hline 1 & Avocet S & 100 & 100 & 100 & 100 & 100 \\
\hline 2 & Avocet $+Y r A$ & 98.3 & 100 & 87.5 & 100 & 100 \\
\hline 3 & Avocet-Yrl & 1.7 & 0 & 0 & 2.6 & 0 \\
\hline 4 & Avocet-Yr2 & 96.6 & 100 & 87.5 & 100 & 100 \\
\hline 5 & Avocet-Yr5 & 0 & 0 & 0 & 0 & \\
\hline 6 & Avocet-Yr6 & 100 & 100 & 100 & 100 & 100 \\
\hline 7 & Avocet- $Y r 7$ & 100 & 100 & 100 & 100 & 100 \\
\hline 8 & Avocet-Yr8 & 88.1 & 91.7 & 50.0 & 97.3 & \\
\hline 9 & Avocet- $Y r 9$ & 98.3 & 100 & 100 & 100 & 100 \\
\hline 10 & Avocet-Yr10 & 16.9 & 0 & 0 & 26.3 & 100 \\
\hline 11 & Avocet-Yr15 & 0 & 0 & 0 & 0 & \\
\hline 12 & Avocet-Yr17 & 100 & 100 & 100 & 100 & 100 \\
\hline 13 & Avocet-Yr24 & 8.5 & 0 & 0 & 10.5 & 100 \\
\hline 14 & Avocet-Yr26 & 10.2 & 0 & 0 & 13.2 & 100 \\
\hline 15 & Avocet-Yr27 & 96.6 & 100 & 75.0 & 100 & 100 \\
\hline 16 & Avocet- $Y r S P$ & 0 & 0 & 0 & 0 & \\
\hline 17 & Avocet-Yr32 & 74.6 & 8.3 & 75.0 & 97.4 & 100 \\
\hline 18 & Avocet- $Y r 28$ & 100 & 100 & 100 & 100 & 100 \\
\hline 19 & Avocet-Yr29 & 100 & 100 & 100 & 100 & 100 \\
\hline 20 & Avocet-Yr31 & 100 & 100 & 100 & 100 & 100 \\
\hline 21 & AC Barrie & 100 & 100 & 100 & 100 & 100 \\
\hline 22 & CDC Teal; $Y r 18+$ & 100 & 100 & 100 & 100 & 100 \\
\hline 23 & Lillian $\operatorname{Yr} 18, \operatorname{Yr} 30, \operatorname{Yr} 36+$ & 67.8 & 16.7 & 0 & 97.4 & \\
\hline 24 & Tyee; YrTye & 3.4 & 0 & 0 & 5.3 & \\
\hline 25 & $\begin{array}{l}\text { Heines VII; } Y r 2 \text {, } \\
\quad Y r V I I, Y r 25, \operatorname{Yr} 11\end{array}$ & 79.7 & 83.3 & 12.5 & 7.9 & 100 \\
\hline 26 & Chinese 166; Yrl & 1.7 & 0 & 0 & 2.6 & \\
\hline 27 & Nord Deprez; Yr3a, Yr4a & 79.7 & 25 & 87.5 & 97.4 & 100 \\
\hline 28 & AC Avonlea & 100 & 100 & 100 & 100 & 100 \\
\hline 29 & $\begin{array}{l}\text { Hybrid } 46 ; Y r 3 b \\
\text { Yr } 4 b, Y r H 46\end{array}$ & 1.7 & 0 & 0 & 2.6 & \\
\hline 30 & Sumwon92*Omar; $\mathrm{YrSu}$ & 66.1 & 8.3 & 25.0 & 97.4 & \\
\hline 31 & Brevis (triticale) & 39.0 & 66.7 & 0 & 10.5 & \\
\hline
\end{tabular}

a Differential number.

b Stripe rust $(Y r)$ gene near-isogenic lines in the Avocet-susceptible (Avocet S) background were developed by the Plant Breeding Institute, the University of Sydney, Australia (Wellings et al. 2004). Refer to Randhawa et al. (2012) for AC Barrie, CDC Teal, Lillian, AC Avonlea and Brevis (triticale); refer to Su et al. (2003) for Heines VII, Nord Deprez, Hybrid 46, and Suwon92*Omar; and refer to Holtz et al. (2013) for Tyee and Chinese 166. 
of the seedlings were each rated independently and then averaged over plants (because there was no significant difference in disease on two leaves) to assess the virulent or avirulent reaction.

Race detection, distribution, frequency, and diversity. An isolate was considered avirulent if it induced IT 0 to 4 and virulent when IT 5 to 9 were observed. Virulence profiles of $P$. striiformis $\mathrm{f}$. sp. tritici isolates were converted into binary notation, with 0 for avirulent and 1 for virulent. A dendrogram was generated from the unweighted pair-group method with arithmetic mean algorithms on the basis of pairwise similarities generated with the simple matching similarity coefficients of the sequential, agglomerative, hierarchical, and nested clustering method. The analysis was conducted using the numerical taxonomy and multivariate analysis system software (NTSYS, version 2.2) (Rohlf 2000). Races were named C-PST-\#, where ' $C$ ' stands for Canada and 'PST' for the Latin name of the fungus.

Discriminant analysis of principal components (DAPC), implemented in the ADEGENET package in the R environment (Jombart et al. 2010), was performed to infer the clustering pattern of isolates based on virulence phenotypes to group isolates and the relation to their geographical location or year of collection. The number of clusters was selected based on the Bayesian information criterion (BIC), as suggested by Jombart et al. (2010). The DAPC, unlike principal component analysis, does not consider total variation in the population but, instead, optimizes variation among groups while minimizing variation within groups. In our case, we were more interested in looking at diversity among groups (races) of the population and not just the total population; thus, we employed DAPC.

Diversity analyses were performed using the virulence analysis tool (VAT) (Schachtel et al. 2012) to correlate diversity with virulence phenotypes, and the clusters generated by DAPC were used to calculate the diversity within each cluster. Isolates were grouped based on their geographic origin to examine diversity within regions. Diversity or distance among regions and clusters was also calculated. Diversity analyses for regions were performed only for Saskatchewan and southern Alberta because there were relatively few isolates from elsewhere. Diversity was analyzed using various indices implemented in the VAT; however, only two indices, the Shannon index $(\mathrm{SH})$ and the Kosman index $\left(K W_{m}\right)$, which are commonly used to determine the diversity of microorganisms and plant pathogens, were considered for making inferences (Kosman 2014; Kosman and Leonard 2007; Schachtel et al. 2012). The $S H$ was calculated as $S H=-\Sigma[p j \ln (p j)]$, in which, $p j$ is the frequency of the $j^{\text {th }}$ race in the sample. The $K W_{m}$ was calculated as $K W_{m}=$ $A s s_{\max }(P, P) / n k$, where $A s s_{\max }(P, P)$ is the maximum value of the sum of distances between a pair of isolates in the population, $n$ is the number of individuals in the population, and $k$ is the number of differentiating factors.

Comparison of race composition based on virulence frequency of $\boldsymbol{P}$. striiformis f. sp. tritici isolates on $\mathbf{Y r}$ genes. Virulence frequency of the isolates representing races in the provinces of Alberta and Saskatchewan were compared with the isolates representing races prevalent in the PNW and the GP of the United States. Virulence frequencies of the isolates were compared mainly for 2011 and 2013, the collection years of the majority of isolates in this study. Stripe rust was epidemic in all four western provinces (British Columbia, Alberta, Saskatchewan, and Manitoba) of Canada in 2011 (Kutcher et al. 2012) and the disease was widespread across Saskatchewan (Brar et al. 2014) and Alberta in 2013 (D. Gaudet, personal communication). The virulence frequencies were calculated for the isolates collected in the years 2011 and 2013 and data on virulence frequency of races of $P$. striiformis $\mathrm{f}$. sp. tritici for the United States was accessed from http://striperust.wsu.edu/races/stripe-rust-race-data.html. The data on virulence frequency of 2011 isolates from Alberta was assessed from the supplementary information in Table 1 provided by Holtz et al. (2013) and combined with Alberta data from the present study. The relationship of races among all regions was further tested by calculating correlation coefficients from the means of the virulence frequencies (means calculated for 2011 and 2013) using the cor.test implemented in the $\mathrm{R}$ environment ( $\mathrm{R}$ Core Team 2014).
The evolutionary changes in $P$. striiformis f. sp. tritici virulence from 2007 to 2013 were also examined for Alberta and Saskatchewan by comparing virulence frequency of isolates among years. The virulence frequency was calculated and compared only for $\mathrm{Yrl}, \mathrm{Yr} 10$, Yr24/26, Yr27, Yr32, and YrTye, because they differentiated most of the races in different studies by Kumar et al. (2012) and Holtz et al. (2013) and the present study. Additionally, genes $Y r 10$ and $Y r 27$ are carried by Canadian wheat 'AC Radiant' and 'Selkirk', respectively. Selkirk is an old variety and was widely grown in Canada during the 1980s (McCallum and DePauw 2008).

\section{Results}

Multivariate analyses of virulence profiles. Virulence frequency of isolates ranged from 0 to $100 \%$ on the 30 wheat differentials (Table 1). Differentials Avocet S, Yr6, Yr7, Yr17, Yr28, and Yr31 were susceptible to all isolates. None of the isolates were virulent on $\mathrm{Yr} 5, \mathrm{Yr} 15$, or $\mathrm{YrSP}$. A virulence frequency of $3 \%$ was detected for $Y r 1$ and 'Hybrid 46' (Table 1). Virulence frequencies for $Y r A$, Yr2, Yr8, Yr9, Yr27, Yr29, Yr32, YrSu, 'Heines VII', and 'Nord Deprez' ranged from 65 to $98 \%$. Canadian wheat 'AC Barrie', 'AC Avonlea', and 'CDC Teal', included as supplemental differentials, were susceptible to all isolates. The virulence frequency on 'Lillian' wheat was $68 \%$. Brevis, the only triticale included in the differential set, was susceptible to $39 \%$ of the isolates.

Virulence analyses differentiated the 59 isolates into 33 races, of which 26 were represented by single isolates (Fig. 1; Table 2). The most common race, C-PST-1, represented 18 isolates (31\%); it was avirulent on $Y r 1, Y r 5, Y r 10, Y r 15, Y r 24 / 26, Y r S P, Y r T y e$, and Hybrid 46. The second most common race, C-PST-2, represented four isolates (7\%) and was avirulent on $\mathrm{Yrl}, \mathrm{Yr} 5, \mathrm{Yr} 10, \mathrm{Yr} 15, \mathrm{Yr} 24 / 26$, Yr32, YrSP, YrSu, YrTye, Hybrid 46, Nord Deprez, and Lillian. The isolate collected from foxtail barley as well as one from wheat belonged to race C-PST-8 (avirulent on $\operatorname{Yrl}, \mathrm{Yr} 5, \mathrm{Yr} 10, \mathrm{Yr} 15$, Yr24/26, YrSP, YrTye, Hybrid 46, Lillian, Heines VII, and Brevis).

All isolates from Saskatchewan, Manitoba, and British Columbia were avirulent on $\mathrm{Yr}$. Isolates virulent on $\mathrm{Yr} 10, \mathrm{Yr} 24, \mathrm{Yr} 26$, and YrTye were not reported in Saskatchewan until 2013 (Table 2). Virulence on $\mathrm{Yr} 10$ was common in isolates sampled from southern Alberta. A race from Saskatchewan virulent on Hybrid 46 was detected in 2011 but was not detected among isolates collected in 2013. Race C-PST-18 (detected in 2011) was represented by only one isolate and was virulent on the fewest differentials (Table 2).

In all, 7 of the 59 isolates included in the present study were characterized previously. Many of the differential wheat genotypes used in those studies were the same as we used in our study, and virulent and avirulent reactions were compared. Isolate W057 (called T-W-09-CRE-33 by Kumar et al. [2012]) was virulent on Yr26 and avirulent on $\operatorname{Yr} 28$ in the Kumar et al. (2012) study but we observed the opposite. Other reactions were the same. Six isolates-W031 (or T203), W033 (or T204), W034 (or T173), W035 (or T174), W055 (or T129), and W056 (or T210)—were included from Holtz et al. (2013). Isolates W034 and W035 had the same reaction on all common differentials in both the Holtz et al. (2013) study and in our study; however, the other isolates differed in their reaction on Yr28. These were reported to be avirulent on $\operatorname{Yr} 28$ (Holtz et al. 2013), whereas they were virulent in our study. The variation in reaction among studies for these isolates may be attributed to differences in disease assessment and differences in experimental conditions. In the field at the adult plant stage, lines carrying $\operatorname{Yr} 28$ give a moderately susceptible to susceptible reaction (R. Kutcher, unpublished data).

In most of the groups, two closely related races differed by virulence on a single resistance gene in the host (Table 2). Additionally, four major groups of isolates (G1 to G4) were detected based on their virulence profiles (Figs. 1 and 2). Races in each group were independent of their geographic origin. Group G4 had only one isolate representing one race and was distantly related to groups G1, G2, and G3 in terms of virulence phenotype or spectrum. Races in groups G1 and G2 were different from G3 and G4 in terms of virulence spectrum and the year of detection. Races in G1 and G2 have a relatively 
narrow virulence spectrum (Fig. 2) and all races were detected before or in 2011. Most of the races in G3 were detected after 2011. Virulence on $\mathrm{Yrl}$ and Hybrid 46 was detected for only one race in G3 (Table 2; Fig. 2). Virulence on YrTye was detected for only two races in G3. The single G4 race was avirulent to $\operatorname{Yrl}, \mathrm{Yr} 5, \mathrm{Yr} 8, \mathrm{Yr} 15, \mathrm{YrSP}$, YrSu, YrTye, Hybrid 46, Lillian, and Brevis (triticale) (Table 1; Fig. 2). The $\mathrm{G} 1$ and $\mathrm{G} 2$ races were avirulent to $\operatorname{Yr} 1, \mathrm{Yr} 5, \operatorname{Yr} 10, \mathrm{Yr} 15, \mathrm{Yr} 24$, Yr26, YrSP, YrTye, and Hybrid 46 (Table 1). The G3 races were

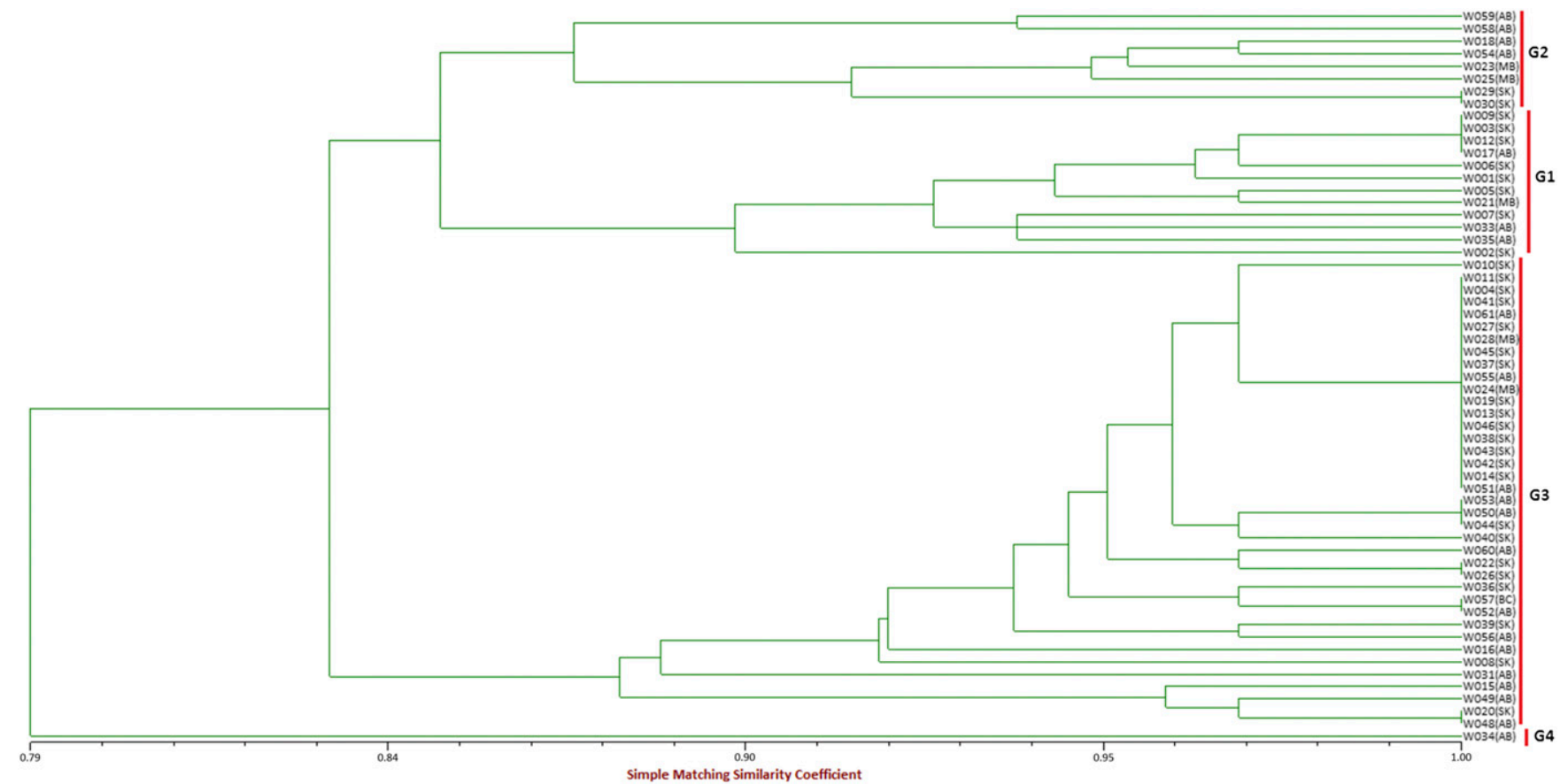

Fig. 1. Similarity dendrogram based on simple matching coefficient of 59 Puccinia striiformis $\mathrm{f}$. $\mathrm{sp}$. tritici isolates collected from western Canada based on virulence to wheat differentials and triticale. Vertical lines to the right show the four major groups among 33 races.

Table 2. Virulence spectra and frequency of Puccinia striiformis f. sp. tritici races sampled from 1984 to 2013 in western Canada ${ }^{a}$

\begin{tabular}{|c|c|c|c|c|c|c|c|c|c|c|c|c|c|c|c|c|c|c|c|c|}
\hline Race & Group & Year ${ }^{\mathbf{b}}$ & Region $^{c}$ & $\operatorname{Yr} A$ & $\operatorname{Yr} 1$ & $\mathrm{Yr} 2$ & $\operatorname{Yr} 8$ & $\operatorname{Yr} 10$ & $\operatorname{Yr} 24$ & Yr 26 & Yr 32 & $\mathrm{Yr} S u$ & $Y r 3 b, 4 b$ & Yr $3 a, 4 a$ & $\operatorname{Yr} 18+36+29$ & Yr $2+H V I I+25$ & $\begin{array}{c}Y r \\
T y e\end{array}$ & $\begin{array}{c}\text { Chinese } \\
166\end{array}$ & $\begin{array}{l}\text { Brevis } \\
\text { (Trit.) }\end{array}$ & Freq $(\%)^{\mathbf{d}}$ \\
\hline C-PST-1 & G3 & 2005 & MB & + & - & + & + & - & - & - & + & + & - & + & + & + & - & - & - & 30.6 \\
\hline C-PST-2 & G1 & 2010 & $\mathrm{AB}$ & + & - & + & + & - & - & - & - & - & - & - & - & + & - & - & + & 6.8 \\
\hline C-PST-3 & G3 & 2012 & $\mathrm{AB}$ & + & - & + & + & + & - & - & + & + & - & + & + & + & - & - & + & 5.1 \\
\hline C-PST-4 & G3 & 2013 & SK & + & - & + & + & - & - & - & + & + & + & + & + & - & - & - & + & 3.4 \\
\hline C-PST-5 & G3 & 2009 & $\mathrm{BC}$ & + & - & + & + & + & - & - & + & + & - & + & + & + & - & - & - & 3.4 \\
\hline C-PST-6 & G3 & 2013 & $\mathrm{AB}, \mathrm{SK}$ & + & - & + & + & + & + & + & + & + & - & + & + & + & - & - & + & 3.4 \\
\hline C-PST-7 & $\mathrm{G} 2$ & 2011 & $\mathrm{AB}$ & + & - & + & - & - & - & - & + & - & - & + & - & - & - & - & - & 1.7 \\
\hline C-PST-8 & G2 & 2013 & SK & + & - & + & + & - & - & - & + & + & - & + & - & - & - & - & - & 3.4 \\
\hline C-PST-9 & G1 & 2011 & SK & + & - & + & + & - & - & - & - & - & - & - & + & + & - & - & + & 1.7 \\
\hline C-PST-10 & G1 & 2011 & SK & + & - & + & + & - & - & - & - & + & - & - & - & + & - & - & + & 1.7 \\
\hline C-PST-11 & G1 & 2011 & SK & + & - & + & + & - & - & - & - & - & - & + & - & + & - & - & + & 1.7 \\
\hline C-PST-12 & G1 & 2005 & MB & + & - & + & + & - & - & - & - & - & - & + & - & + & - & - & - & 1.7 \\
\hline C-PST-13 & G1 & 2011 & SK & + & - & + & + & - & - & - & - & - & - & - & - & - & - & - & - & 1.7 \\
\hline C-PST-14 & G1 & 2011 & $\mathrm{AB}$ & + & - & + & + & - & - & - & + & - & - & - & - & + & - & - & - & 1.7 \\
\hline C-PST-15 & G1 & 2011 & $\mathrm{AB}$ & + & - & + & - & - & - & - & - & - & - & - & - & + & - & - & - & 1.7 \\
\hline C-PST-16 & G1 & 2011 & SK & + & - & + & + & - & - & - & - & - & - & + & + & - & - & - & + & 1.7 \\
\hline C-PST-17 & G2 & 2011 & $\mathrm{AB}$ & + & - & + & - & - & - & - & - & - & - & + & - & - & - & - & - & 1.7 \\
\hline C-PST-18 & G2 & 2011 & $\mathrm{AB}$ & + & - & - & - & - & - & - & - & - & - & + & - & - & - & - & - & 1.7 \\
\hline C-PST-19 & $\mathrm{G} 2$ & 2005 & MB & + & - & + & - & - & - & - & + & - & - & + & - & + & - & - & - & 1.7 \\
\hline C-PST-20 & $\mathrm{G} 2$ & 2005 & MB & + & - & + & + & - & - & - & + & - & - & - & - & - & - & - & - & 1.7 \\
\hline C-PST-21 & $\mathrm{G} 2$ & 2007 & $\mathrm{AB}$ & - & - & + & - & - & - & - & + & - & - & + & - & - & - & - & - & 1.7 \\
\hline C-PST-22 & G3 & 2011 & SK & + & - & + & + & - & - & - & - & + & - & + & + & + & - & - & - & 1.7 \\
\hline C-PST-23 & G3 & 2013 & SK & + & - & + & + & - & - & - & + & + & - & - & + & + & - & - & + & 1.7 \\
\hline C-PST-24 & G3 & 2013 & $\mathrm{AB}$ & + & - & + & + & - & - & - & + & + & + & + & + & - & - & - & - & 1.7 \\
\hline C-PST-25 & G3 & 2013 & SK & + & - & + & + & - & - & - & + & + & - & + & + & + & - & - & + & 1.7 \\
\hline C-PST-26 & G3 & 2013 & SK & + & - & + & + & - & - & - & + & + & - & + & + & + & + & - & + & 1.7 \\
\hline C-PST-27 & G3 & 2011 & $\mathrm{AB}$ & + & + & + & + & - & - & - & + & + & - & + & + & + & + & + & + & 1.7 \\
\hline C-PST-28 & G3 & 2011 & $\mathrm{AB}$ & + & - & + & - & - & - & - & + & - & - & + & + & + & - & - & + & 1.7 \\
\hline C-PST-29 & G3 & 2011 & SK & + & - & + & + & - & - & - & + & + & + & + & - & + & - & - & + & 1.7 \\
\hline C-PST-30 & G3 & 2010 & $\mathrm{AB}$ & + & - & + & + & + & + & + & + & - & - & + & + & + & - & - & + & 1.7 \\
\hline C-PST-31 & G3 & 2013 & $\mathrm{AB}$ & + & - & + & + & + & + & + & + & + & - & - & + & + & - & - & + & 1.7 \\
\hline C-PST-32 & G3 & 2011 & $\mathrm{AB}$ & + & - & + & + & - & - & + & - & + & - & + & + & + & - & - & + & 1.7 \\
\hline C-PST-33 & G4 & 2011 & $\mathrm{AB}$ & + & - & + & - & + & + & + & + & - & - & + & - & + & - & - & - & 1.7 \\
\hline
\end{tabular}

a Avocet differentials carrying $Y r 5$ and $Y r 15$ were resistant to all isolates, and those carrying no genes (Avocet S), $Y r 6, Y r 7, Y r 9, Y r 12, Y r 17, Y r 28, Y r 29$, and $Y r 31$ were susceptible to all isolates. Wheat AC Barrie, AC Avonlea, and CDC Teal were susceptible to all isolates. Symbols: $+=$ virulent reaction and $-=$ avirulent reaction.

b Year of first detection.

${ }^{\mathrm{c}}$ Region of first detection.

${ }^{\mathrm{d}}$ Race frequency. 
avirulent only on $\operatorname{Yr} 5, \operatorname{Yr} 15$, and $\mathrm{YrSP}$ (Table 1). Virulence on $\mathrm{YrA}$, $Y r 2, Y r 9$, and $Y r 27$ was $100 \%$ in $\mathrm{G} 1, \mathrm{G} 3$, and G4, whereas races in $\mathrm{G} 2$ were variable to the genes (Table 1). Similarly, virulence on $\mathrm{Yr} 10$ and $Y r 24 / 26$ was only detected in G3 and G4 races. Groups 3 and 4 were distinguished by their virulence pattern on $Y r 1, Y r 8, Y r 24 / 26, Y r T y e$, $\mathrm{YrSu}$, Hybrid 46, Lillian, and Brevis triticale. Of these seven previously characterized isolates, W034 (T173) was the only isolate in G4 (Fig. 1). Isolates W031 (T203), W055 (T129), W056 (T210), and W057 (T-W-09-CRE-33) formed G3 (Fig. 1). Races C-PST-14 (W034/T173) and C-PST-15 (W035) were reported only from Alberta in 2011 (Table 2).

DAPC. The nonparametric DAPC of virulence profiles of $P$. striiformis f. sp. tritici isolates identified at least three groups $(\mathrm{K}=3)$ or clusters (Fig. 3), supported by the BIC curve (Supplementary Figs. S2 and S3). The clusters are based on races rather than their collection locations.

The three clusters identified by DAPC are similar to the groups in Figure 1, except for G4, which was merged into Cluster 1. Clusters 1 and 3 represent races with a relatively narrow virulence spectrum. These were detected in or before 2011.

Diversity analyses. The 59 P. striiformis $\mathrm{f}$. sp. tritici isolates were divided into subpopulations based on differences in virulence (Table 3). The $\mathrm{SH}$ for either Alberta or Saskatchewan isolates or for the three population clusters was not significantly different (Table 3). However, the $K W_{m}$ indicated greater diversity in the $P$. striiformis f. sp. tritici population in Alberta compared with the Saskatchewan population. Similarly, for the three clusters, the value was higher for Cluster 2 (G2 and G4).

Comparison of races based on virulence frequency of $P$. striiformis f. sp. tritici isolates on $\mathrm{Yr}$ genes. Virulence frequency of isolates representing races detected in 2011 and 2013 in the United States and in the western Canadian provinces of Alberta and Saskatchewan were compared (Table 4). The PNW and the GP regions of the United States were considered for comparison with Alberta and Saskatchewan because of their proximity to western Canada and the likely contribution to inoculum arriving to Alberta and Saskatchewan from these regions (Fig. 4). Virulence on $\mathrm{Yr} 5$ and Yr15 was not detected in the United States or Canada (Table 4). Virulence on $\mathrm{Yrl}, \mathrm{YrSP}$, and YrTye was detected only in the PNW and Alberta. The virulence frequency on $\mathrm{Yr} 10$ was higher in Alberta compared with other regions. Virulence on $\mathrm{Yr} 10, \mathrm{Yr} 24$, and $\mathrm{Yr} 32$ was not

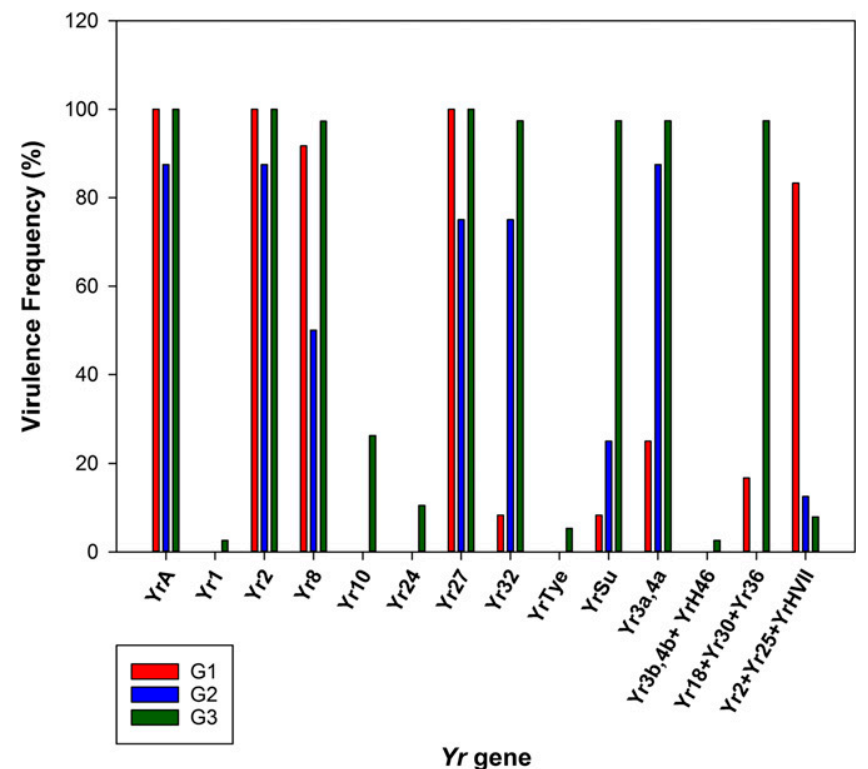

Fig. 2. Virulence frequency of the Puccinia striiformis $\mathrm{f}$. $\mathrm{sp}$. tritici isolates from the three groups ( $G 1$ to $G 3$ ) on a few genes differentiating all 59 isolates into four groups. Group $\mathrm{G} 4$, with only one isolate, was either virulent or avirulent on these genes and, thus, excluded from the graph. G4 was virulent only on Yr2, Yr10, Yr24, Yr27, Yr32, Nord Deprez, and Heines VII. detected in the GP. There was a significant and strong positive correlation between virulence frequencies from the United States and those from Saskatchewan and Alberta. However, correlation coefficients were higher (but not significantly different) for the PNW and Saskatchewan, as compared with the PNW and Alberta. The relatively high correlation between the PNW and Saskatchewan could be attributed to the virulence frequencies on $\mathrm{Yr} 10$ and $\mathrm{Yr} 24$, which were similar. On the other hand, correlation coefficient values were significantly higher for the GP and Saskatchewan compared with the GP and Alberta. Correlation was the highest between Alberta and Saskatchewan.

From 2007 to 2011, no P. striiformis f. sp. tritici race in Alberta or Saskatchewan carried virulence for $Y r 1 ; 2011$ was the first year when the pathogen gained virulence on $\mathrm{Yrl}$ (Table 5). Virulence on $\mathrm{Yrl}$ was detected only for races prevalent in Alberta. Virulence on Yr10 was very low in 2007, absent in 2008, but common between 2009 and 2013. The first race virulent on $\mathrm{YrlO}$ in Saskatchewan was detected in 2013. The races virulent on $\mathrm{Yr} 24 / 26$ were more frequent in 2007 and 2008 compared with other years, and the frequency of races was the lowest in 2010. The $\operatorname{Yr} 27$ gene was not completely defeated before 2008 , because races lacking virulence were detected in 2007. Races virulent on $\operatorname{Yr} 32$ were less frequent in 2008 compared with other years, and the pathogen completely defeated the gene in Alberta and Saskatchewan in 2011 and 2013 (Table 5) (Holtz et al. 2013). Virulence on YrTye was gained in 2011 and the frequency was higher in Alberta compared with Saskatchewan (virulence detected in 2013; Tables 4 and 5).

\section{Discussion}

Stripe rust has been a serious problem in southern Alberta for more than 40 years and its long-term presence in southern Alberta can be attributed to the greater area under irrigation, proximity to the PNW of the United States (where stripe rust occurs every year), and the relatively greater diversity of wheat varieties (Xi et al. 2015). The 2011 epidemic in southern Alberta and in Saskatchewan created awareness of the economic impact of stripe rust. It was triggered by unusually high spring precipitation that resulted in high moisture conditions in spring wheat crops, which created favorable crop canopy conditions for the pathogen (Brar et al. 2016). This and the large diversity of races that appeared in 2011, including a race virulent on $\operatorname{Yr} 10$, which was deployed in the popular winter wheat AC Radiant, were major contributing factors to this epidemic. The distribution of stripe rust was also widespread in 2012 (R. Kutcher, unpublished data) and 2013 (Brar 2015; Brar et al. 2014). Identification and comparison of races among regions of the world is difficult due to differences in the wheat genotypes composing the differential set (Wan and Chen 2014). For this reason, very few studies have compared race structure or virulence variation. In our study, we have attempted to compare and correlate $P$. striiformis f. sp. tritici population virulence frequencies from southern Alberta with Saskatchewan, and with the PNW and the GP of the United States.

New races of $P$. striiformis f. sp. tritici are believed to evolve from stepwise mutation rather than events such as somatic recombination (Hovmøller et al. 2002; Wellings and McIntosh 1990). If somatic recombination were common, the new races would be expected to have a combination of virulences (Steele et al. 2001). There are a few races in our study that suggest virulence recombination from coexisting races (data not shown).

Races virulent on $\operatorname{YrSP}$ were reported for the first time in 1990 in Alberta and again in 1991 and 1995, although at low frequencies (Su et al. 2003). A race virulent on $\mathrm{Yrl}$ was first reported from Alberta in 1989 (Su et al. 2003). The low frequency and instability of races virulent on these genes indicates that these races were not common in the $P$. striiformis f. sp. tritici population prevalent in western Canada. This might be associated with the lack of selective advantage of these virulent races. If these genes were not carried by commercial wheat varieties in Canada, there would be no selection pressure on $P$. striiformis f. sp. tritici races virulent on these genes. Races virulent on $\mathrm{Yrl}$ are frequently recovered from the PNW compared with the other regions, where the races virulent on $\mathrm{Yrl}$ are either absent or are 
recovered sporadically at very low frequency (Tables 1 and 4). Virulence on YrSP in 2011 and 2013 was detected in the United States among races collected from R1, R5 (Table 4), R10, and R11 only (data not shown); the frequency of these races was low. Although the frequency of races virulent on $Y r l$ was high in the United States, most of the isolates were collected from R1 and R5 (close to British Columbia) and none were collected from R8 and R9 (Wan and Chen 2014) (race data, http://striperust.wsu.edu). The absence of races virulent on $\mathrm{Yrl}$ in R8 and R9 may be due to the Rocky Mountains, which act as a barrier between the PNW, British Columbia, and Alberta; none of the races from Saskatchewan were virulent on $\mathrm{Yrl}$. Virulence on $\mathrm{Yr} 15$ was never detected in the United States, although it was reported by Su et al. (2003) in Canada.
Two races (C-PST-18 and C-PST-21) were avirulent on $\mathrm{YrA}, \mathrm{Yr} 2$, $Y r 8$, and $Y r 27$ (Tables 1 and 2), even though these $Y r$ genes are defeated by races prevalent in western Canada. These races, which are present at a very low frequency, might be old (detected before 2000), or they could be the result of back-mutations to avirulence on $Y r A$ and $Y r 2$. Back-mutation was observed previously in $P$. striiformis f. sp. tritici for genes $Y r A, Y r 9$, and $Y r 32$ (Hovmøller and Justesen 2007; Wellings and McIntosh 1990). All races detected after 2000 in western Canada are virulent on $Y r 6, Y r 7$, and $Y r 9$, and most are virulent on $\operatorname{Yr} 8$. Gene $\operatorname{Yr} 6$ is present in a wide range of bread and durum wheat varieties in Asia and Europe (Chilosi and Johnson 1990), which explains the high virulence frequency worldwide on $\operatorname{Yr} 6$. Virulence on Yr7 can be explained through its use in 'Thatcher' ( $Y r 7)$ and old landraces (Sharma-Poudyal et al. 2013). Thatcher cultivation was

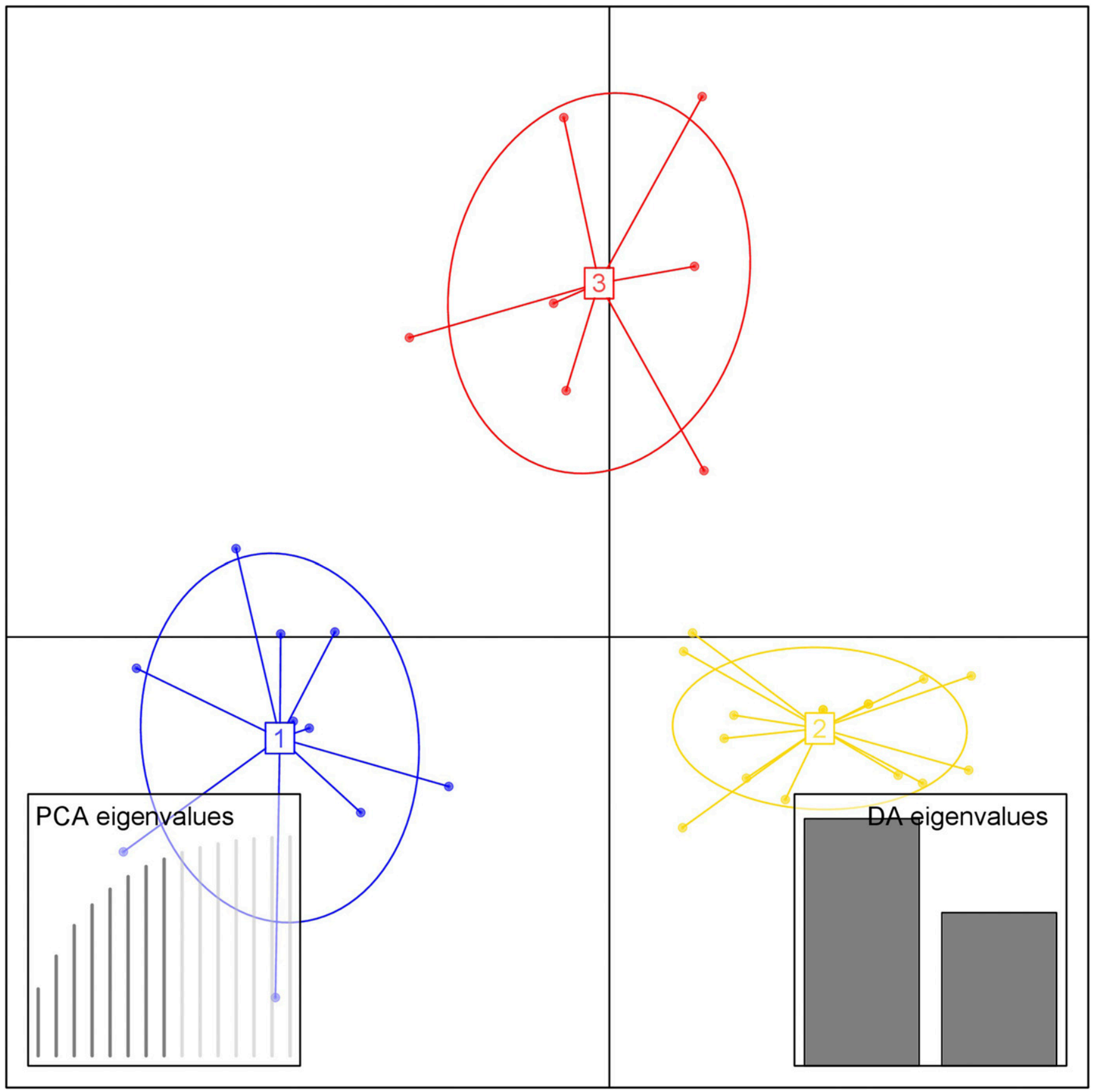

Fig. 3. Discriminant analyses (DA) of principal components for 33 Puccinia striiformis f. sp. tritici races detected in western Canada, suggesting at least three subpopulations. The bar plot in the bottom right-hand corner represents the DA eigenvalues for two main principal components or discriminant functions and the plot on the left-hand side shows the eigenvalues of the principal component analyses (PCA). Clusters 1 and 3 consist of the races detected in or before 2011 (with relatively narrow virulence spectrum), whereas cluster 2 consists of races collected after 2011 (with added virulence on Yr genes compared with clusters 1 and 3). 
widespread in western Canada from the 1940s to the early 1970s (McCallum and DePauw 2008), which could have exerted selection pressure on prevalent races of stripe rust at the time. Additionally, virulence on $\mathrm{Yr} 6$ and $\mathrm{Yr} 7 \mathrm{in}$ the United States is indicated by races virulent on 'Fielder' and 'Lee', respectively (Chen 2005). Virulence on $\operatorname{Yr} 8$ worldwide can be explained by extreme selection pressure on the pathogen population, because this gene was derived from Aegilops comosa and is present in many grass species (Stubbs 1985). Similarly, $\operatorname{Yr} 9$ was obtained from rye and was used extensively in breeding programs worldwide, which resulted in the emergence of virulent races (Sharma-Poudyal et al. 2013). The spread of $P$. striiformis f. sp. tritici races virulent on $\operatorname{Yr} 8$ and $\operatorname{Yr} 9$ to Canada is the result of its existence in the United States, as Chen et al. (2010) speculated regarding its movement from Mexico to the northern United States and then to Canada (Chen 2005).

A race represented by a single isolate in our study, named C-PST27, has a virulence phenotype similar to that of the Kranich race group detected in Europe (Hovmøller et al. 2016); that is, compatible IT of 6 to 9 on $Y r 1, Y r 2, Y r 3, Y r 6, Y r 7, Y r 8, Y r 9, Y r 17, Y r 25$ (in Hybrid 46), and Yr32 (with some additional virulence on other differentials with defeated genes). The races in the Kranich group are known recombinant races and are able to cause high levels of disease on race-specific adult plant resistance (APR) lines (Hovmøller et al. 2016). The race in our study has shown signs of recombination (G. S. Brar, unpublished data) but its interaction with APR genes and those in Kranich wheat need to be tested for further confirmation that it belongs to the Kranich race.

Virulence on gene $\mathrm{Yr}$ 17, which originated from Triticum ventricosum and was deployed in various hexaploid wheat varieties using the
VPM1 line, was fixed for all isolates examined in the present study. Kumar et al. (2012) and Holtz et al. (2013) observed similar results for $\operatorname{Yr17}$, with a virulence frequency of 95 to $100 \%$. The gene was reported to vary from intermediate to susceptible IT in studies by Bariana and McIntosh (1994) and Milus et al. (2015), depending on temperature, assessment and rating methods, light conditions, and other factors. $\mathrm{Yrl7}$ is considered a seedling resistance gene but, in some studies, high IT have been scored on seedlings when adult plants were resistant (Milus et al. 2015). As such, characterization of isolates on $\operatorname{Yr} 17$ can be difficult, especially when IT are intermediate (Milus et al. 2015). It was also recently recommended to incorporate known avirulent, partially virulent, and virulent isolates as controls because the reaction of $Y r 17$ depends on many critical factors, including temperature during incubation and disease rating (first or second leaf), as discussed by Milus et al. (2015). In the present study, IT for all interactions were high, ranging from 7 to 9 (susceptible), which may be due to environmental conditions maintained in the study. However, no known avirulent isolate was included to compare the IT with the virulent ones. The temperature ranged from a low of $12^{\circ} \mathrm{C}$ to a high of $17^{\circ} \mathrm{C}$ (increasing and decreasing gradually), high relative humidity was 60 to $80 \%$, and light intensity was high, which could have contributed to susceptible IT because these are critical requirements for expression of susceptible genotypes to races carrying virulence for $\operatorname{Yr} 17$. Additionally, the high virulence frequency on Yrl7 could also be attributed to the selection pressure on the gene, because this gene may be linked to stem rust and leaf rust resistance genes $\operatorname{Sr} 38$ and $L r 37$, respectively (all derived from the VPM1 line), which were deployed in the Canadian wheat 'CDC Falcon' and 'McClintock' from VPM1 during 2001 to 2002 (McCallum and

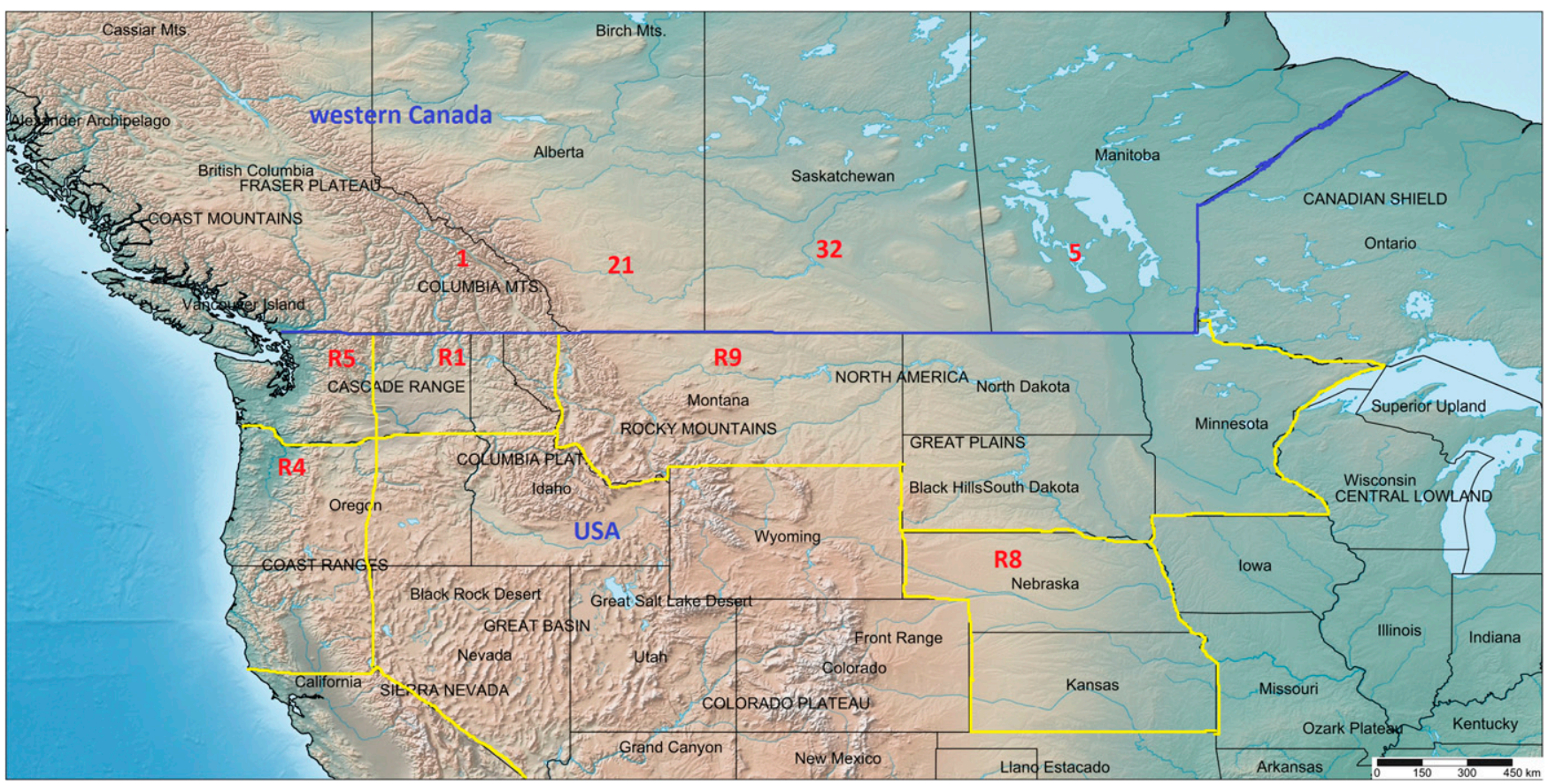

Fig. 4. Twelve stripe rust epidemiological regions in the United States of America and the provinces of British Columbia, Alberta, Saskatchewan, and Manitoba in western Canada. Numbers in the western Canada map shows the number of Puccinia striiformis $\mathrm{f}$. sp. tritici isolates collected and characterized from each province in the present study.

Table 3. Diversity indices (implemented in the virulence analysis tool) used for diversity within populations of Puccinia striiformis f. sp. tritici from Saskatchewan and Alberta $^{\mathrm{a}}$

\begin{tabular}{lccccc}
\hline Diversity index & Alberta & Saskatchewan & Cluster 1 (G1+G4) & Cluster 2 (G3) & Cluster 3 (G2) \\
\hline Shannon index & 2.780 & & 2.234 & 2.027 & 2.022 \\
Kosman index & 0.208 & 0.096 & 0.107 & 0.073 & 2.036 \\
Kosman distance & & 0.065 & & $\ldots$ & $\ldots$
\end{tabular}

\footnotetext{
${ }^{a}$ Clusters and groups in reference to discriminant analysis of principal components and NTSYSpc results.
}

b Between Alberta and Saskatchewan. 
DePauw 2008). These varieties were quite popular among wheat growers, at least for the first few years after registration (B. Fowler, winter wheat breeder, personal communication). Similarly, $\operatorname{Yr} 32$ is susceptible to all races from Alberta, most of the races in Saskatchewan, and a few from the PNW.

Genes $Y r 24$ and $Y r 26$ are reported to be the same gene (Li et al. 2006). These genes (or this gene) restrict the pathogen's growth rate and very few uredia or pustules form on leaves (slow-rusting), although the leaves turn necrotic in these interactions. All races in our study had an avirulent reaction on both genes, except for one isolate (race C-PST-32) from Alberta, which was avirulent on $Y r 24$ but virulent on $\operatorname{Yr26}$. The difference could be attributed to incorrect classification during rating; the difference in disease severity score was small (average score of 4 for $\mathrm{Yr} 24$ and 5 for $\mathrm{Yr} 26$ ). Therefore, we also believe that $Y r 24$ and $Y r 26$ are the same gene. Virulence on $Y r 27$ was detected for all races except two from Alberta, and the same trend was observed for races prevalent in Alberta (Holtz et al. 2013; Kumar et al. 2012). The $Y r 27$ gene was deployed in a wide range of wheat varieties in western Asia and Africa but the severe epidemic of 2010 (Xi et al. 2015) resulted in resistance breakdown. This gene is linked to leaf rust resistance genes $L r 13$ and $L r 23$ and also to stem rust resistance gene $\mathrm{Sr} 10$, all of which were used extensively in breeding programs (McDonald et al. 2004). This gene is also present in the Canadian wheat Selkirk and varieties derived from Selkirk (Xi et al. 2015), which were widely cultivated over a large area until the late 1980s (McCallum and DePauw, 2008). This may have resulted in the loss of $\mathrm{Yr} 27$ to virulent races due to extreme selection pressure.

Brevis triticale was included in the differential set because triticale is reported to be resistant to most $P$. striiformis $\mathrm{f}$. sp. tritici races (Wellings et al. 2012). In fact, the frequency of races virulent on Brevis was high $(39 \%)$. Brevis and other triticale varieties were reported to be highly resistant to stripe rust in field nurseries at plant maturity in western Canada in 2011 (Randhawa et al. 2012) and, in 2013 and 2014, in stripe rust nurseries in Saskatchewan (Brar 2015; R. Kutcher, unpublished data). Considering that rust inoculations for race characterization were performed at the seedling stage, field resistance may be due to APR genes in triticale germplasm in Canada.

Table 4. Means and correlation coefficients of the virulence frequency of the Puccinia striiformis f. sp. tritici isolates collected in years 2011 and 2013 from the Pacific Northwest (PNW) and the upper Great Plains (GP) of the United States of America and the Canadian provinces of Alberta (AB) and Saskatchewan (SK)

\begin{tabular}{|c|c|c|c|c|}
\hline$Y r$ gene $^{a}$ & $\mathbf{P N W}^{\mathbf{b}}$ & $\mathbf{G P}^{\mathbf{c}}$ & $\mathbf{A} \mathbf{B}^{\mathbf{d}}$ & $\mathbf{S K}^{\mathrm{e}}$ \\
\hline Yrl & 62.4 & 0 & 17.4 & 0 \\
\hline Yr6 & 87.9 & 88.2 & 100 & 100 \\
\hline$Y r 7$ & 79.2 & 88.2 & 100 & 100 \\
\hline $\operatorname{Yr} 8$ & 78.0 & 88.2 & 87.9 & 100 \\
\hline $\operatorname{Yr} 9$ & 92.3 & 88.2 & 100 & 100 \\
\hline $\operatorname{Yr} 10$ & 4.7 & 0 & 30.4 & 6.3 \\
\hline $\operatorname{Yr} 17$ & 81.8 & 88.2 & 100 & 100 \\
\hline $\operatorname{Yr} 24$ & 3.3 & 0 & 19.6 & 3.1 \\
\hline$Y r 27$ & 85.7 & 79.4 & 100 & 100 \\
\hline Yr32 & 3.3 & 0 & 100 & 71.9 \\
\hline$Y r S P$ & 12.4 & 0 & 2.2 & 0 \\
\hline YrTye & 63.6 & 0 & 15.2 & 0 \\
\hline \multirow[t]{2}{*}{ Correlation $^{\mathrm{f}}$} & with $\mathrm{AB}=70 \%$ & with $\mathrm{AB}=85 \%$ & with SK $=97 \%$ & $\cdots$ \\
\hline & with SK $=74 \%$ & with SK $=93 \%$ & $\ldots$ & $\ldots$ \\
\hline
\end{tabular}

a Virulence frequency on $Y r 5$ and $Y r 15$ was 0 for all regions.

${ }^{\mathrm{b}}$ Calculated from a total of 428 P. striiformis $\mathrm{f}$. $\mathrm{sp}$. tritici isolates collected from these regions in 2011 and 2013.

c Calculated from a total of 34 P. striiformis $\mathrm{f}$. sp. tritici isolates collected from these regions in 2011 and 2013.

${ }^{\mathrm{d}}$ Calculated from a total of $46 P$. striiformis $\mathrm{f}$. sp. tritici isolates collected from Alberta in 2011 and 2013

${ }^{\mathrm{e}}$ Calculated from a total of 32 P. striiformis $\mathrm{f}$. sp. tritici isolates collected from Saskatchewan in 2011 and 2013.

${ }^{\mathrm{f}}$ Strong correlations $(>66 \% ; P<0.05)$. There was a significant difference in correlation of $\mathrm{AB}$ with the $\mathrm{GP}$ and correlation of SK with the GP $(P<0.05)$.
The hard red spring wheat Lillian carries APR genes $\operatorname{Yrl8}$ and Yr30 and high-temperature APR gene Yr36, which are not expressed at the seedling stage (DePauw et al. 2005) (R. DePauw, personal communication). It was included as a supplemental line in the differential set because it was planted widely in Canada in 2005 to 2012 and is still commonly cultivated in Alberta and Saskatchewan. Some races were observed to be avirulent on Lillian at the seedling stage, which may indicate that Lillian also has unknown seedling resistance genes. Because Lillian carries three APR genes, it is highly resistant to stripe rust races in field trials at the adult stage (Kutcher and Liu 2014; Randhawa et al. 2012).

The majority of races were avirulent on $\operatorname{Yr} 10$ (Table 2). In all, 7 of 10 isolates (representing six races) virulent on $\mathrm{Yr} 10$ were recovered from Alberta and 1 from British Columbia but only 2 from Saskatchewan. This gene is present in Canadian AC Radiant winter wheat, which became susceptible to stripe rust in 2010 and 2011 in southern Alberta (Kutcher et al. 2012). This indicated that races virulent on $\mathrm{YrlO}$ are not yet common in the $P$. striiformis $\mathrm{f}$. sp. tritici population prevalent in Saskatchewan. The virulence frequency on $\mathrm{YrlO}$ in southern Alberta was higher in 2013 (Holtz et al. 2013) than reported in 2012 (Kumar et al. 2012) and previous years (Su et al. 2003). Races virulent on YrlO are more common in southern British Columbia ( $\mathrm{Su}$ et al. 2003) and southern Alberta (Holtz et al. 2013) than in Saskatchewan and Manitoba. These races may have arrived as airborne inoculum from the PNW of the United States, where races virulent on $\mathrm{Yr} 10$ occur almost every year, although at low frequency (virulence frequency was quite high during 2004 to 2007) in regions R1, R2, R4, and R5 (Chen et al. 2010; Wan and Chen, 2014). Selection pressure on $\mathrm{Yr} 10$, present in AC Radiant, which was grown over a large area over a number of years (2007 to 2010), could have resulted in the increase in these races. Further evidence is the high virulence frequency of $P$. striiformis f. sp. tritici on $\mathrm{YrlO}$ which was observed in Alberta (Table 4).

The stripe rust pathogen has the potential to overwinter in Alberta (Conner et al. 1988; Kumar et al. 2013) and was reported there early in the 2014 season (D. Gaudet and K. Kumar, personal communication), which was unusual. The growing season in western Canada is short; therefore, planting and harvesting of spring and winter wheat can overlap, resulting in a "green bridge" for $P$. striiformis $\mathrm{f}$. sp. tritici urediniospores produced on overwintering winter wheat (Kumar et al. 2013), most of which are susceptible to stripe rust (Anonymous 2010). Most Canadian spring wheat varieties are deployed with either $\operatorname{Yr} 18$ or Yr36, which are APR genes. The pleiotropic Yrl8 gene is widespread in Canadian spring wheat varieties because it also conditions leaf rust (Lr34) and powdery mildew $(P m 38)$ resistance (Randhawa et al. 2012); however, $\operatorname{Yr} 18$ is not deployed in Canadian western soft white spring (CWSWS) or Canadian western amber durum varieties (Randhawa et al. 2012). Most Canadian wheat varieties lack allstage resistance genes, and virulence frequency of $P$. striiformis $\mathrm{f}$. sp. tritici races on CWSWS varieties in Canada (Table 1) is very high (Holtz et al. 2013; Randhawa et al. 2012).

Races virulent on $\mathrm{Yrl}, \mathrm{YrSP}$, and $\mathrm{YrTye}$ are observed in the western United States (PNW). Virulence frequency on these genes in

Table 5. Evolution of Puccinia striiformis f. sp. tritici virulence (measured by virulence frequency) in Alberta and Saskatchewan between 2007 and 2013 on differentiating and commonly deployed $Y r$ genes in wheat varieties ${ }^{\mathrm{a}}$

\begin{tabular}{lcccccc}
\hline & \multicolumn{7}{c}{ Frequency (\%) } \\
\cline { 2 - 7 } Year (isolates) $^{\mathbf{b}}$ & Yr1 & Yr10 & Yr24/26 & Yr27 & Yr32 & YrTye \\
\hline $2007(24)$ & 0 & 4.2 & 16.7 & 83.3 & 75.0 & $\ldots$ \\
$2008(9)$ & 0 & 0 & 22.2 & 100 & 55.6 & $\ldots$ \\
$2009(9)$ & 0 & 22.2 & 11.1 & 100 & 88.9 & $\ldots$ \\
$2010(24)$ & 0 & 16.7 & 4.2 & 100 & 95.8 & 0 \\
$2011(54)$ & 14.8 & 18.5 & 11.1 & 100 & 77.8 & 11.1 \\
$2013(26)^{\mathbf{c}}$ & 0 & 19.2 & 11.5 & 100 & 100 & 3.9 \\
\hline
\end{tabular}

a Data collected for 2007 to 2008 from Kumar et al. (2012) and 2009 to 2011 from Holtz et al. (2013) along with 2011 to 2013 data from the present study; indicates no data collected.

${ }^{\mathrm{b}}$ Year and number of $P$. striiformis $\mathrm{f}$. sp. tritici isolates examined

${ }^{c}$ Results for 2013 are only from the province of Saskatchewan. 
Alberta and British Columbia is similar to that in the PNW of the United States; virulence was observed previously in British Columbia and Alberta but never in Saskatchewan (Holtz et al. 2013; Kumar et al. 2012; Su et al. 2003; Wan and Chen 2014). Additionally, virulence frequency on $\operatorname{Yr} 10, \operatorname{Yr} 24 / 26, \operatorname{Yr} 28$, and $\operatorname{Yr} 32$ is different for Saskatchewan races compared with races from Alberta or British Columbia. Virulence on $\mathrm{Yr} 1, \mathrm{Yr} 10, \mathrm{Yr} 32, \mathrm{YrSP}$, and $\mathrm{YrTye}$ was detected more commonly in races from the PNW than in those from states east of the Rocky Mountains (Wan and Chen 2014) (Table 4; race data, http://striperust.wsu.edu). This suggests that the $P$. striiformis f. sp. tritici population in Saskatchewan may be a result of inoculum coming from both the PNW, which is also supported by the prevailing westerly and southerly winds during the summer, and the GP of the United States.

The diversity distance of $P$. striiformis f. sp. tritici populations prevalent in southern Alberta and Saskatchewan is low according to the $K W_{m}$ of 0.065 (Table 3). The low diversity between the two provinces could be attributed to the differences in virulence frequencies of races on $\mathrm{Yr}$ genes and race composition. Additionally, this low index value can be attributed to the lack of any geographical barrier between the two provinces, resulting in a race mixture. However, diversity within populations from the two provinces varied (Table 3 ). The $S H$ was previously reported to be less accurate compared with the $K W_{m}$ in determining race diversity in $P$. striiformis f. sp. tritici populations (Wan and Chen 2012). Therefore, the $K W_{m}$ was used to make inferences on diversity. The $K W_{m}$ suggested that, within the $P$. striiformis f. sp. tritici population, diversity is greater among isolates collected in Alberta than in Saskatchewan. This may again be attributed to the proximity of southern Alberta to the PNW, where stripe rust is a major problem and the $P$. striiformis f. sp. tritici population is very diverse. In addition, there is a greater genetic diversity of $R$ genes against $P$. striiformis $\mathrm{f}$. sp. tritici in wheat varieties grown in the PNW, resulting in a high frequency of evolution in the $P$. striiformis $\mathrm{f}$. sp. tritici population (Chen et al. 2010). The greater diversity of $P$. striiformis f. sp. tritici in southern Alberta could also be attributed to the existence of races with unique virulence combinations on $Y r 1, Y r 10, Y r S P$, and YrTye (Table 2) (Holtz et al. 2013). The differences between the virulence frequencies east (GP) and west (PNW) of the Rocky Mountains could be due to the presence of the mountains, which separate these regions, and due to more favorable conditions for stripe rust in the PNW (Chen 2005). The lower race diversity in the states east of the Rocky Mountains compared with those to the west was also reported by Wan and Chen (2012).

For some of the important $R$ genes, the virulence frequency of $P$. striiformis f. sp. tritici races follows the order PNW $>$ Alberta $>$ Saskatchewan, which may be related to the decrease in inoculum intensity along wind trajectories from the PNW into western Canada. This is in agreement with the theory that disease intensity starts to decrease with distance from the source of inoculum (Mundt et al. 2010). The strong correlation between virulence frequency of races from the PNW and Alberta and Saskatchewan populations are indicative of a close relationship in race distribution among these areas. Our study is in agreement with Xi et al. (2015), where a strong correlation (many similar virulences) between races from Alberta and the PNW was detected. However, the correlation between Alberta and the GP is significantly lower than the correlation between Saskatchewan and the GP. This suggests greater differences among races in Alberta relative to Saskatchewan that are related to the upper GP. A very strong correlation (97\%) between virulence frequencies in Alberta and Saskatchewan further indicates the mixing of windborne inoculum of races from these two provinces, which occurs due to lack of any geographical barrier. This is further indicated by the representation of the most common race (C-PST-1) detected in our study by isolates from all three prairie provinces. This suggests that the races in Alberta and Saskatchewan are a mixture of inoculum from the PNW and the $\mathrm{GP}$; however, the intensity of inoculum from the GP is greater in Saskatchewan compared with Alberta.

From 2007 to 2013, races of $P$. striiformis f. sp. tritici have changed in terms of gain of virulence on Yrl, YrTye, Yr10, Yr27, and $Y r 32$. The races virulent on $Y r 24 / 26$ and $Y r 32$ did not increase as frequently as those virulent on $\operatorname{Yr} 10$ and $\mathrm{Yr} 27$. This can again be attributed to selection pressure on the pathogen induced by the $\mathrm{Ca}$ nadian AC Radiant and Selkirk, which carry Yr10 and Yr27. Races carrying virulence to other genes depend more on factors causing variation in the PNW and GP of the United States.

Other than the arrival of inoculum from the PNW, as mentioned earlier, the pathogen may also have the potential to overwinter in Alberta in some years (Conner et al. 1988; Kumar et al. 2013; Xi et al. 2015). As a result of overwintering, the disease may appear earlier in some seasons than others (Xi et al. 2015), which results in a greater number of generations of urediniospores and, as a result, will increase the probability of mutation and somatic hybridization events. Additionally, irrigated fields and the greater diversity of wheat varieties cultivated in southern Alberta compared with Saskatchewan may result in greater diversity of the pathogen population. This diversity in the pathogen population has also been confirmed using whole-genome sequencing and genotyping of the pathogen population (Brar 2015).

In conclusion, this study indicated that the PNW of the United States plays a major role in the $P$. striiformis $\mathrm{f}$. $\mathrm{sp}$. tritici race composition in Alberta and Saskatchewan; and the GP region is as important as the PNW to Saskatchewan in terms of airborne P. striiformis f. sp. tritici inoculum. Disease pressure of stripe rust in Saskatchewan is highly dependent on the disease levels in the United States. Additionally, the $P$. striiformis $\mathrm{f}$. sp. tritici population in Saskatchewan is not as diverse as it is in Alberta, which may be because of the different sources of inoculum, diversity of the wheat varieties cultivated, or pathogen factors (adaptation to warmer climates and overwintering potential in Alberta). The overwintering potential of $P$. striiformis f. sp. tritici in western Canada, the susceptibility of Canadian wheat varieties to stripe rust at the seedling stage, and the green bridge between winter and spring wheat provide favorable conditions for stripe rust epidemics in western Canada. Thus, these factors make regular and frequent pathogen characterization very important.

\section{Acknowledgments}

This research was supported by the Western Grains Research Foundation, the Agriculture Development Fund of Saskatchewan Ministry of Agriculture, and the Natural Sciences and Engineering Research Council. We thank D. Gaudet, A. Laroche, B. McCallum, K. Kumar, and M. Holtz for providing pathogen isolates from Alberta and Manitoba; staff of the Cereal \& Flax Pathology lab at University of Saskatchewan for help in collection of infected wheat leaves from across the province of Saskatchewan; and S. Banniza (Plant Pathologist at the Crop Development Centre, University of Saskatchewan) and T. Fetch (Agriculture and Agri-Food Canada, Brandon, MB, Canada) for critical review of this manuscript prior to submission

\section{Literature Cited}

Anonymous. 2010. Agriculture Statistics Year Book 2012. Alberta Agriculture and Rural Development, Statistics and Data Development Branch, Edmonton, AB, Canada.

Brar, G. S. 2015. Population structure of Puccinia striiformis f. sp. tritici, the cause of wheat stripe rust, in western Canada. M.Sc. thesis, University of Saskatchewan, Saskatoon, SK Canada. https://ecommons.usask.ca/handle/10388/ETD-2015-032015

Brar, G. S., Liu, J., and Kutcher, H. R. 2014. Stripe rust of winter wheat, spring wheat and barley in Saskatchewan in 2013. Can. Plant Dis. Surv. 94:124-126.

Brar, G. S., McCallum, B. D., Gaudet, D. A., Puchalski, B. J., Fernandez, M. R., and Kutcher, H. R. 2016. Stripe rust disease dynamics in southern Alberta, Saskatchewan, and Manitoba, 2009-2014. Can. J. Plant Pathol. 38:112-127

Bariana, H. S., and McIntosh, R. A. 1994. Characterization and origin of rust and powdery mildew resistance genes in VPM1 wheat. Euphytica 76:53-61.

Chen, X. M. 2005. Epidemiology and control of stripe rust (Puccinia striiformis $\mathrm{f}$. sp. tritici) on wheat. Can. J. Plant Pathol. 27:314-337.

Chen, X. M., Penman, L., Wan, A., and Cheng, P. 2010. Virulence races of Puccinia striiformis f. sp. tritici in 2006 and 2007 and development of wheat stripe rust and distributions, dynamics, and evolutionary relationships of races from 2000 to 2007 in the United States. Can. J. Plant Pathol. 32:315-333.

Chilosi, G., and Johnson, R. 1990. Resistance to races of Puccinia striiformis in seedling of Italian wheats and possible presence of the $\operatorname{Yr} 6$ gene in some durum cultivars. J. Genet. Breed. 44:13-20.

Conner, R. L., Thomas, J. B., and Kuzyk, A. D. 1988. Overwintering of stripe rust in southern Alberta. Can. Plant Dis. Surv. 68:153-155.

DePauw, R. M., Townley-Smith, T. F., Humphreys, G., Knox, R. E., Clarke, F. E. and Clarke, J. M. 2005. Lillian hard red spring wheat. Can. J. Plant Sci. 85 397-401. 
Holtz, M. D., Kumar, K., and Xi, K. 2013. Virulence phenotypes of Puccinia striiformis in Alberta from 2009-2011. Can. J. Plant Pathol. 35:241-250.

Hovmøller, M. S., and Justesen, A. F. 2007. Appearance of atypical Puccinia striiformis f. sp. tritici phenotypes in north-western Europe. Aust. J. Agric. Res. 58:518-524.

Hovmøller, M. S., Justesen, A. F., and Brown, J. K. M. 2002. Clonality and long distance migration of Puccinia striiformis f. sp. tritici in north-west Europe. Plant Pathol. 51:24-32.

Hovmøller, M. S., Walter, S., Bayles, R. A., Hubbard, A., Flath, K., Sommerfeldt, N., Leconte, M., Czembor, P., Rodriguez-Algaba, J. Thach, T., Hansen, J. G., Lassen, P., Justesen, A. F., Ali, S., and de Vallavielle-Pope, C. 2016. Replacement of the European wheat yellow rust population by new races from the centre of diversity in the near-Himalayan region. Plant Pathol. 65:402-411.

Jombart, T., Devillard, S., and Balloux, F. 2010. Discriminant analysis of principal components: A new method for the analysis of genetically structured populations. BMC Genet. 11:94.

Kosman, E. 2014. Measuring diversity: From individuals to populations. Eur. J. Plant Pathol. 138:467-486.

Kosman, E., and Leonard, K. J. 2007. Conceptual analysis of methods applied to assessment of diversity within and distance between populations with asexual or mixed mode of reproduction. New Phytol. 174:683-696.

Kumar, K., Holtz, M. D., Xi, K., and Turkington, T. K. 2012. Virulence of Puccinia striiformis on wheat and barley in central Alberta. Can. J. Plant Pathol. 34:551-561.

Kumar, K., Holtz, M. D., Xi, K., and Turkington, T. K. 2013. Overwintering potential of the stripe rust pathogen (Puccinia striiformis) in central Alberta. Can. J. Plant Pathol. 35:304-314.

Kutcher, H., Randhawa, H., Puchalski, B., Wogsberg, S., Graf, R., and Gaudet, D. 2012. The 2011 stripe rust epidemic in western Canada. Page 22 in: Proc. 13th Int. Cereal Rusts Powdery Mildews Conf. Beijing.

Kutcher, H. R., and Liu, J. 2014. Fungicide application at flowering provides effective control of stripe rust in susceptible wheat cultivars in western Canada. In: Proc. 2nd Int. Stripe Rust Symp. Izmir, Turkey.

Li, Z. F., Xia, X. C., Zhou, X. C., Niu, Y. C., He, Z. H., Zhang, Y., Li, G. Q., Wan, A. M., Wang, D. S., Chen, X. M., Lu, Q. L., and Singh, R. P. 2006. Seedling and slow rusting resistance to stripe rust in Chinese common wheats. Plant Dis. 90:1302-1312.

Line, R. F. 2002. Stripe rust of wheat and barley in North America: A retrospective historical review. Annu. Rev. Phytopathol. 40:75-118.

Line, R. F., and Qayoum, A. 1991. Virulence, aggressiveness, evolution, and distribution of races of Puccinia striiformis (the cause of stripe rust of wheat) in North America, 1968-87. U. S. Dep. Agric. Tech. Bull. No. 1788.

Marchildon, G. P., ed. 2009. Introduction. Pages 1-4 in: Immigration \& Settlement 1870-1939. Canadian Plains Research Center Press.

McCallum, B. D., and DePauw, R. M. 2008. A review of the wheat cultivars grown in the Canadian prairies. Can. J. Plant Sci. 88:649-677.

McCallum, B. D., Pearse, P. G., Fetch, T., Gaudet, D., Tekauz, A., Seto-Goh, P., Xi, K., and Turkington, T. K. 2007. Stripe rust of wheat and barley in Manitoba, Saskatchewan and Alberta in 2006. Can. Plant Dis. Surv. 87:66.

McDonald, D. B., McIntosh, R. A., Wellings, C. R., Singh, R. P., and Nelson, J. C. 2004. Cytogenetical studies in wheat. XIX. Location and linkage studies on gene $\operatorname{Yr} 27$ for resistance to stripe (yellow) rust. Euphytica 136:239-248.

McNeal, F. H., Konzak, C. F., Smith, E. P., Tate, W. S., and Russell, T. S. 1971. A uniform system for recording and processing cereal research data. U. S. Dep. Agric. Agric. Res. Serv. Bull. 34-121.

Milus, E. A., Kristensen, K., and Hovmøller, M. S. 2009. Evidence for increased aggressiveness in a recent widespread strain of Puccinia striiformis $\mathrm{f}$. sp. tritici causing stripe rust of wheat. Phytopathol. 99:89-94.

Milus, E. A., Lee, K. D., and Brown-Guedira, G. 2015. Characterization of stripe rust resistance in wheat lines with resistance gene $\mathrm{Yr} 17$ and implications for evaluating resistance and virulence. Phytopathol. 105:1123-1130.
Milus, E. A., Seyran, E., and McNew, R. 2006. Aggressiveness of Puccinia striiformis f. sp. tritici isolates in the south-central United States. Plant Dis. 90:847-852.

Mundt, C. C., Sackett, K. E., Wallace, L. D., Cowger, C., and Dudley, J. P. 2010 Aerial dispersal and multiple-scale spread of epidemic disease. EcoHealth 6: 546-552.

Puchalski, B., Gaudet, D., Randhawa, H., Wogsberg, S., Kundrik, K., Frick, M., Despins, T., and Laroche, A. 2013. The occurrence of stripe rust in southern Alberta 2012-2013. In: 34th Annu. Meet. Plant Pathol. Soc. Alberta. Brooks, AB, Canada.

R Core Team. 2014. R: A Language and Environment for Statistical Computing, Vol. 2014. R Foundation for Statistical Computing, Vienna.

Randhawa, H., Puchalski, B. J., Frick, M., Goyal, A., Despins, T., Graf, R. J., Laroche, A., and Gaudet, D. A. 2012. Stripe rust resistance among western Canadian spring wheat and triticale varieties. Can. J. Plant Sci. 92:713-722.

Rohlf, F. 2000. NTSYS-pc Numerical Taxonomy and Multivariate Analysis, Version 2.10z Manual. Applied Biostatistics, New York.

Sanford, G. B., and Broadfoot, W. C. 1932. Epidemiology of stripe rust in western Canada. Sci. Agric. 13:77-96.

Schachtel, G. A., Dinoor, A., Herrmann, A., and Kosman, E. 2012. Comprehensive evaluation of virulence and resistance data: A new analysis tool. Plant Dis. 96: 1060-1063

Sharma-Poudyal, D., Chen, X. M., Wan, A. M., Zhan, G. M., Kang, Z. S., Cao, S. Q., Jin, S. L., Morgounov, A., Akin, G., Mert, Z., Shah, S. J. A., Bux, H., Ashraf, M., Sharma, R. C., Madariaga, R., Puri, K. D., Wellings, C., Xi, K. Q., Wanyera, R. Manninger, K., Ganzález, M. I., Koyda, M., Sanin, S., and Patzek, L. J. 2013. Virulence characterization of international collections of the wheat stripe rust pathogen, Puccinia striiformis f. sp. tritici. Plant Dis 97:379-386.

Steele, K. A., Humphreys, E., Wellings, C. R., and Dickinson, M. J. 2001. Support for a stepwise mutation model for pathogen evolution in Australasian Puccinia striiformis f. sp. tritici by use of molecular markers. Plant Pathol. 50:174-180.

Stubbs, R. W. 1985. Stripe rust. Pages 61-101 in: Cereal Rusts, Vol. II. Disease, Distribution, Epidemiology, and Control. A. P. Roelfs and W. R. Bushnell, eds. Academic Press, New York.

Su, H., Conner, R. L., Graf, R. J., and Kuzyk, A. D. 2003. Virulence of Puccinia striiformis $\mathrm{f}$. sp. tritici, cause of stripe rust on wheat, in western Canada from 1984-2002. Can. J. Plant Pathol. 25:312-319.

Turkington, T. K., McCallum, B. D., Fetch, T. G., Jr., Xi, K., Kumar, K., Gaudet, D. A., Olfert, O. O., Weiss, R. M., and Soroka, J. J. 2009. Wind trajectories and cereal rust risk, western Canada, 2007. (Abstr.) Can. J. Plant Pathol. 31: 147

Wan, A. M., and Chen, X. M. 2012. Virulence, frequency, and distribution of races of Puccinia striiformis f. sp. tritici and Puccinia striiformis f. sp. hordei identified in the United States in 2008 and 2009. Plant Dis. 96:67-74.

Wan, A. M., and Chen, X. M. 2014. Virulence characterization of Puccinia striiformis $\mathrm{f}$. sp. tritici using a new set of $Y r$ single-gene line differentials in the United States in 2010. Plant Dis. 98:1534-1542.

Wellings, C., Snyman, J. E., Robake, J. E., and Bansal, U. 2012. Stripe rust resistance in triticale in Australia: Pathogen change exposes genetic vulnerability. Pages 38-39 in: Proc. 13th Int. Cereal Rusts Powdery Mildews Conf. Beijing.

Wellings, C. R., and McIntosh, R. A. 1990. Puccinia striiformis f. sp. tritici in Australasia: Pathogenic changes during the first 10 years. Plant Pathol. 39: 316-325.

Wellings, C. R., Singh, R. P., McIntosh, R. A., and Pretorius, Z. A. 2004. The development and application of near isogenic lines for the stripe (yellow) rust pathosystem. Page A1.39 in: Abstracts of Proc. 11th Int. Cereal Rusts and Powdery Mildew Conf., Norwich, England.

Xi, K., Kumar, K., Holtz, M. D., Turkington, T. K., and Chapman, B. 2015. Understanding the development and management of stripe rust in central Alberta. Can. J. Plant Pathol. 37:21-39. 